\title{
Influence of Different Sources of Dietary Fats on Fatty Acid Profile of Striped Snakehead (Channa Striatus) Fish Carcass
}

\author{
Prem Prakash Srivastava ${ }^{1,2, *}$, Rajesh Dayal ${ }^{1}$, Anita Bhatnagar ${ }^{3}$, Shipra Chowdhary ${ }^{1}$, \\ Akhilesh Kumar Yadav ${ }^{4}$, Wazir Singh Lakra, ${ }^{1,5}$ \\ ${ }^{1}$ ICAR - National Bureau of Fish Genetic Resources, Canal Ring Road, Teli Bagh, Lucknow - 226002 , UP, India \\ ${ }^{2}$ Fish Nutrition, Biochemistry and Physiology Division, ICAR - Central Institute of Fisheries Education, Panch Marg, Off Yari Road, \\ Mumbai-400 061, MS, India \\ ${ }^{3}$ Department of Zoology, Kurukshetra University, Kurukshetra-139 119, Haryana, India \\ ${ }^{4}$ Aquaculture Research Training Unit, ICAR - National Bureau of Fish Genetic Resources, Chinhat, Faizabad Road, Lucknow- 227 105, \\ UP, India \\ ${ }^{5}$ ICAR - Central Institute of Fisheries Education, Panch Marg, Off Yari Road, Mumbai-400 061, MS, India \\ *Corresponding Author: ppsicar@gmail.com
}

Copyright (C) 2014 Horizon Research Publishing All rights reserved.

\begin{abstract}
Various dietary fats were used to assess their impact on the fatty acid profile of snakehead murrel, saul (Channa striatus). The saul grow-out (av. wt. $27.36 \pm 0.09$ to $32.54 \pm 0.41 \mathrm{~g})$ were fed for 12-weeks with seven experimental diets (F1, F2, F3, F4, F5, F6 and a control, F7 of natural foodstuffs, NATFO). F1 (L3HUF) contains $0.5 \%$ n-3 fatty acid \& $7.5 \%$ saturated oil; F2 (H3HUF) contains $1.0 \%$ n-3 fatty acid \& 7.0\% saturated oil; F3 (MUSOL) contains $8.0 \%$ mustard oil; F4 (LINOL) contains $8.0 \%$ linseed oil; F5 (MIXOL) contains $4.0 \%$ mustard oil and $4.0 \%$ linseed oil; F6 (SATOL) contains $8.0 \%$ saturated oil. The muscle polyunsaturated fatty acids (PUFA) contents varied with different dietary lipids level which impacted on deposition of fatty acid in flesh. The muscle unsaturated fatty acids, including Docosahexaenoic acid (22:6n3, DHA) and Eicosapentanoic Acid \{C20:5n-3, EPA), levels, were comparatively higher in MIXOL diet followed by H3HUF than in the other diets, indicating selective deposition of various fatty acids in each feeding trial. It was concluded that dietary fats in the diet has role in the carcass composition of fatty acid profile in Channa striatus and the MIXOL (contains mustard oil and linseed oil: 1:1 w/w) could be safely used for better deposition of beneficial healthy fatty acids like EPA and DHA. The addition of mustard oil and linseed oil in the diet are comparative better if we look towards economizing the cost of the brood-stock feed in comparison to the addition of pure fatty acids in the fish diets.
\end{abstract}

Keywords Dietary Fats, Fatty Acids, Carcass, Channa Striatus, Saul, Grow-Out

\section{Introduction}

It is reported[1] that fish reared in intensive culture systems require all nutrients in a complete diet. Information on nutritional requirements of major dietary components such as protein and energy is a prerequisite for the formulation of an inexpensive and balanced diet for the fishes. India has huge potential for the production of cheaper plant sources e.g. de-oiled cakes like linseed oil cake etc. rich in essential fatty acid (EFA, omega-3 HUFA) which can be utilized as source of lipid in carnivorous fish nutrition not only for growth purposes but also for gonadal maturation through dietary manipulations. Recycling of these agro-based by-products, like mustard oil cake, linseed oil cake etc. can be used in place of animal origin oils as source of lipid and EFA. Thus, the fatty acid composition of these various ingredients of plant origin have a good source of HUFA which can be utilized for carnivore fishes nutrition. And these can be very well used in place of animal lipid source, and can be studied for the deposition of nutrients in terms of flesh and maturation of the female fishes as well. Sarowar et al. [2] have studied the impacts of different diets on growth and survival of $C$. striatus grow-outs. Influence of dietary lipid/protein ratio requirement has been studied in C. striatus [3]. Since the fish oil is not only costly but becoming less available, there is an urgent need to assess the dietary potential of various other available sources of fat from both animal and plant sources. In global scenario, the emphasis is being given to dietary replacement of animal fat with less expensive plant fat $[5,7]$. Replacement of fish oil by vegetable oils has proved in many fishes without impacting on growth performances [4-7]. However, the impacts of various dietary oils on lipid metabolism of fish are still not very 
clear, particularly where fish oil provide the only source of highly unsaturated fatty acids, very much essential for catfishes. Variation in dietary oils may lead to imbalances in the essential or non-essential fatty acids, and may be differently affecting tissue profile.

Fish lipids are important because of their high levels of polyunsaturated fatty acids (PUFA), which have been reported to reduce the risk of cardiac diseases [8] and lower plasma triacylglycerol levels [9]. In addition, they can reduce the symptoms of physiological alterations $[10,11]$. Lipid content and fatty acid composition in fish are known to vary significantly depending on the availability of food items to fish and environmental conditions $[12,13]$. Previous studies have shown that n-3 PUFA of marine animals vary depending on various biological and environmental factors, such as taxonomy, diet of the animals, water temperature and the latitude at which they were harvested [14].

The present study was taken up to evaluate the utilization impact of dietary lipids on the carcass fatty acid profile by the striped murrel, C. striatus. The aim of the present study was to assess the impact of different dietary fats in the edible tissue composition of muscle and FA profile enrichment with essential fatty acid of this commercially important fish.

\section{Materials and Methods}

\subsection{Feed Preparation and Feeding}

After the acclimation period of 7 days Six type of feeds were formulated having similar feed ingredients in same quantities excepting different source of fat namely low level of highly unsaturated fatty acid (L3HUF, F1); high level of highly unsaturated fatty acid (H3HUF, F2); mustard oil (MUSOL, F3); linseed oil (LINOL, F4); mixed oil (MIXOL, F5); saturated fat (SATOL, F6) and a control (NATFO, F7) comprising of natural foodstuffs (Table 1). Six diets (L3HUF, F1; H3HUF, F2; MUSOL, F3; LINOL, F4; MIXOL, F5; SATOL, F6) and a control (NATFO, F7) with natural food. F1, contains $0.5 \% \mathrm{n}-3$ fatty acid and $7.5 \%$ saturated oil; F2, contains $1.0 \% \mathrm{n}-3$ fatty acid and $7.0 \%$ saturated oil; F3, contains $8.0 \%$ mustard oil; F4, contains $8.0 \%$ linseed oil; F5, contains $4.0 \%$ mustard oil and $4 \%$ linseed oil; F6, contains $8 \%$ saturated oils. (Table 1).

In order to evaluate the effect of different oil sources on the carcass fatty acid profile of C. striatus, the experiment was conducted in indoor condition in 14 (7 types of feed, 2 replicates) round plastic pools of 300 litre capacity, each filled-up with 100 litre tube well water. Each having two replications, stocked with 20 grow-out having an initial average weight $27.36 \pm 0.09 \mathrm{~g}$ to $32.54 \pm 0.41 \mathrm{~g}$ were plotted in each of the plastic pool after proper acclimatization. The tanks were provided aeration from a portable aerator round the clock. During the experiment, the fishes were fed twice a day at 10:00 and 17:00 hours ad libitum per day. Rearing pools were cleaned every second day and about half of the water was replaced with fresh bore-well water to reduce the nitrogenous waste accumulated as debris and fecal matters.

Table 1. Ingredients composition (w/w) of feeds

\begin{tabular}{|c|c|c|c|c|c|c|c|}
\hline $\begin{array}{c}\text { Feed } \\
\text { Ingredients }\end{array}$ & $\begin{array}{c}\text { F-1 } \\
\text { (L3HUF) }\end{array}$ & $\begin{array}{c}\text { F-2 } \\
\text { (H3HUF) }\end{array}$ & $\begin{array}{c}\text { F-3 } \\
\text { (MUSOL) }\end{array}$ & $\begin{array}{c}\text { F-4 } \\
\text { (LINOL) }\end{array}$ & $\begin{array}{c}\text { F-5 } \\
\text { (MIXOL) }\end{array}$ & $\begin{array}{c}\text { F-6 } \\
\text { (SATOL) }\end{array}$ & $\begin{array}{c}\text { F-7 } \\
\text { (NATFO) }\end{array}$ \\
\hline Soybean meal & 41.0 & 41.0 & 41.0 & 41.0 & 41.0 & 41.0 & - \\
\hline Starch Soluble & 25.0 & 25.0 & 25.0 & 25.0 & 25.0 & 25.0 & - \\
\hline Casein & 20.0 & 20.0 & 20.0 & 20.0 & 20.0 & 20.0 & - \\
\hline $\begin{array}{c}\text { Carboxy Methyl } \\
\text { Cellulose }\end{array}$ & 2.0 & 2.0 & 2.0 & 2.0 & 2.0 & 2.0 & - \\
\hline $\begin{array}{c}\text { Papain } \\
\text { Vitamin \& Mineral } \\
\text { Mix. }\end{array}$ & 0.5 & 0.5 & 0.5 & 0.5 & 0.5 & 0.5 & - \\
\hline $\begin{array}{c}\text { Omega - 3 HUFA } \\
\text { Saturated Oil }\end{array}$ & 0.5 & 3.5 & 3.5 & 3.5 & 3.5 & 3.5 & - \\
\hline $\begin{array}{r}\text { Mustard Oil } \\
\text { Linseed Oil }\end{array}$ & -7.5 & - & - & - & - & - \\
\hline
\end{tabular}




\subsection{Lipid Extraction}

Total lipid was extracted from muscle following Folch[15]. Muscle tissue $(5 \mathrm{~g})$ was homogenized in 10 volume of methanol $(\mathrm{w} / \mathrm{v})$ followed by 20 volume of chloroform (w/v) in a homogenizer (ART Miccra, Germany). The homogenate was filtered (using a funnel with a folded defatted filter paper) to recover the liquid phase and the filter residue was re-homogenized with a second volume of chloroform-methanol. The filtrate was washed with 0.2 volume $(4 \mathrm{ml}$ for $20 \mathrm{ml})$ of $0.9 \% \mathrm{NaCl}$ solution and phases were vigorously mixed. The mixture was poured into a separating funnel and allowed to separate. The lower chloroform phase containing lipids was collected and evaporated under vacuum in a rotary evaporator to bring down the volume to 2-3 $\mathrm{ml}$. Further evaporation of chloroform was done under nitrogen stream and residue was weighed to quantify the amount of lipid extracted. The lipid residue was re-dissolved in chloroform/ methanol $(2: 1, \mathrm{v} / \mathrm{v})$ and then stored in a $25 \mathrm{ml}$ conical flask with glass stopper under nitrogen at $-20^{\circ} \mathrm{C}$ until used.

\subsection{Preparation of Fatty Acid Methyl Esters (FAME)}

The method as per AOAC[16] was followed to esterify the lipid. FAME was prepared from the isolated lipids by heating with the methanolic $\mathrm{NaOH}$ and then with BF3 methanol for esterification. An aliquot of $5 \mathrm{ml} \mathrm{n}$-heptane was added to recover the methyl esters in organic phase. The mixture was washed with saturated $\mathrm{NaCl}$ solution and two phases were separated using a separating funnel. The upper $\mathrm{n}$-heptane phase was collected and stored in $10 \mathrm{ml}$ all glass vials until further analysis.

\subsection{Gas Chromatography - Mass Spectrometry (GC-MS)}

Fatty acid methyl esters were separated using a Shimadzu QP2010 quadruple Gas Chromatography Mass Spectrometer (GCMS) equipped with a Carbowax (30 m x $0.25 \mathrm{~mm}$ ID; $0.25-\mu \mathrm{m}$ film thickness) capillary column (Cromlab S.A.). Helium was used as the carrier gas. Injector and detector temperatures were set at $250{ }^{\circ} \mathrm{C}$. Injection was performed in split mode (1:15). The column temperature was programmed initially at $50{ }^{\circ} \mathrm{C}$ for $2 \mathrm{~min}$ and then increased at a rate of $10{ }^{\circ} \mathrm{C}$ per min to a final temperature of $230{ }^{\circ} \mathrm{C}$. FAME was separated at constant pressure $(23.1 \mathrm{kpa})$ and peaks were identified by comparing standard mass spectra with the relative abundances of $\mathrm{m} / \mathrm{z}$ ranging from 40 to 550 . The values of fatty acids are presented in peak area percentage of total identified fatty acids.

\section{Results and Discussion}

The data on total lipid content (\%) recorded in the muscle tissue of Channa striatus significant differences $(\mathrm{p}<0.05)$ were observed in different feedings(F1-F7). The total lipid content in muscle was found to be in the range of $7.2+0.4$ to $9.5 \pm 0.4 \%$. According to the one suggested by Kleimenov[17], fishes belongs to the group of low fat fishes having an average lipid content of $2-8 \%$. The lipid contents in the carcass of fishes as well as prey animals have been reported to be very high [18]. As the fish consume prey with moderate lipid content, the additional lipid would be deposited in the body of fishes due to higher lipid levels in the feed.

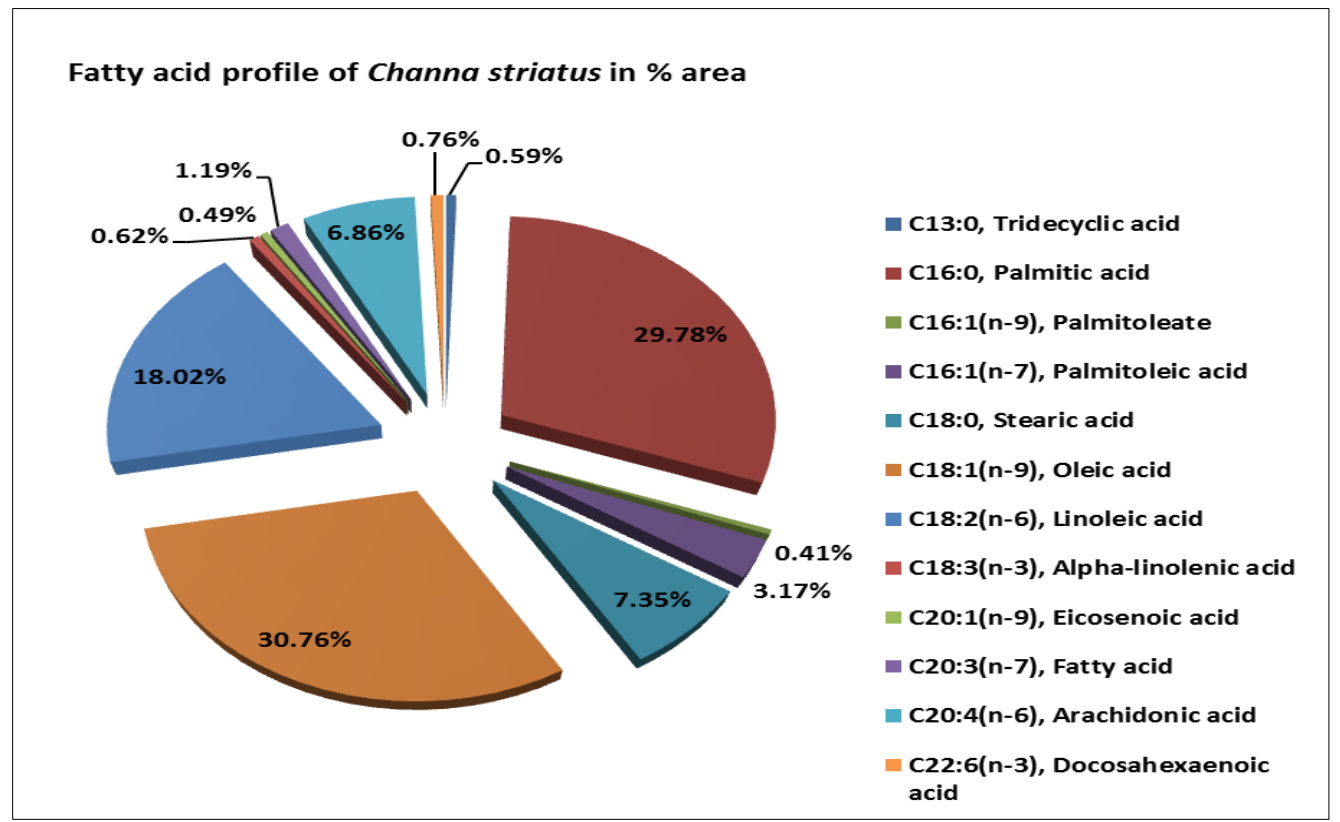

Figure 1. Fatty acid profile of Channa striatus fed with $\mathrm{F}_{1}$ (L3HUF) 
Fatty acid profile of Channa striatus in \% area

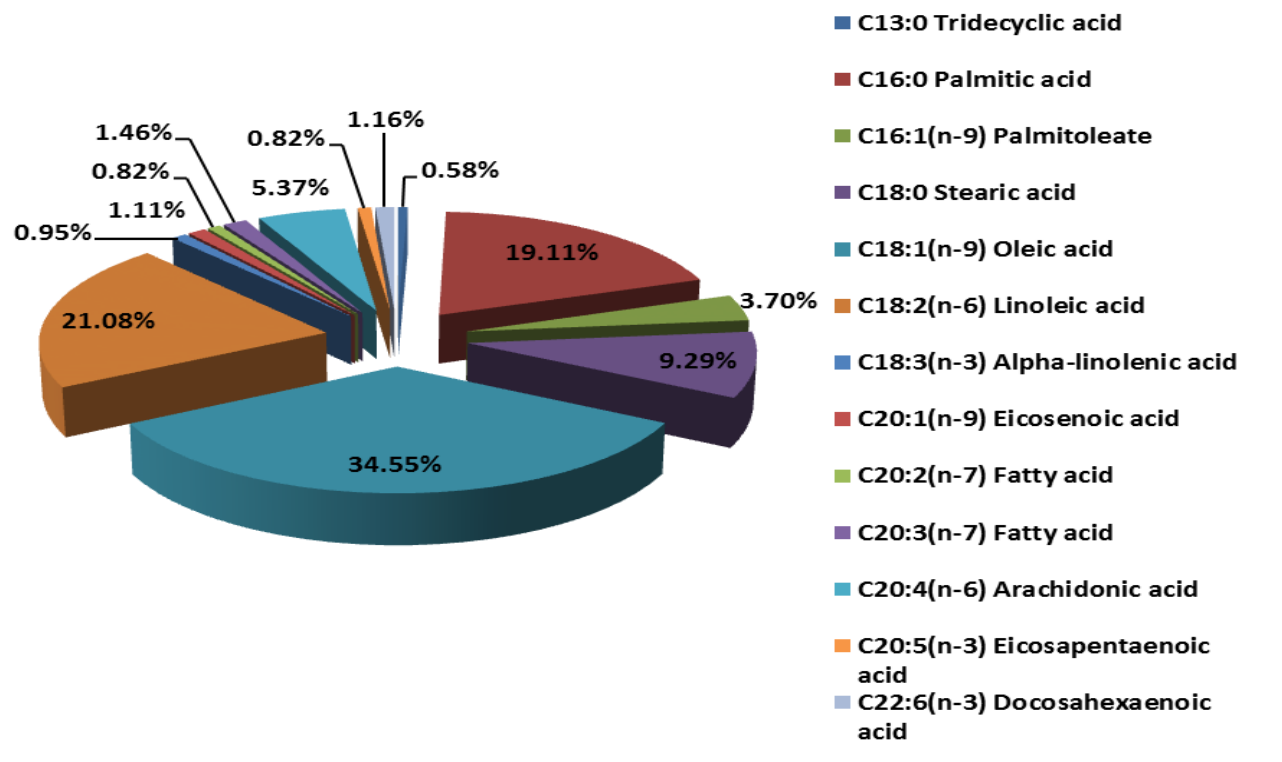

Figure 2. Fatty acid profile of Channa striatus fed with $\mathrm{F}_{2}(\mathrm{H} 3 \mathrm{HUF})$

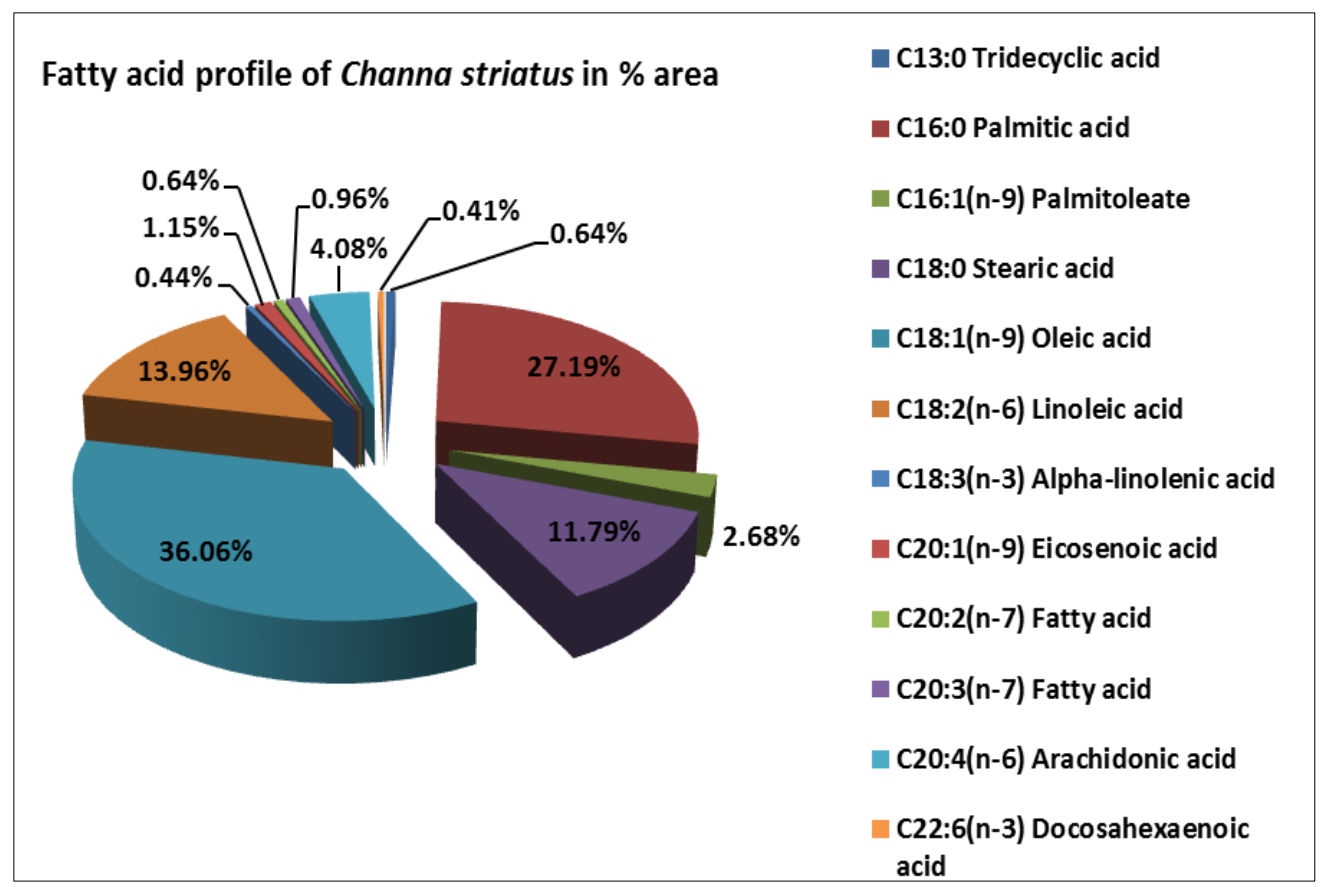

Figure 3. Fatty acid profile of Channa striatus fed with $\mathrm{F}_{3}$ (MUSOL) 
Fatty acid profile of Channa striatus in \% area

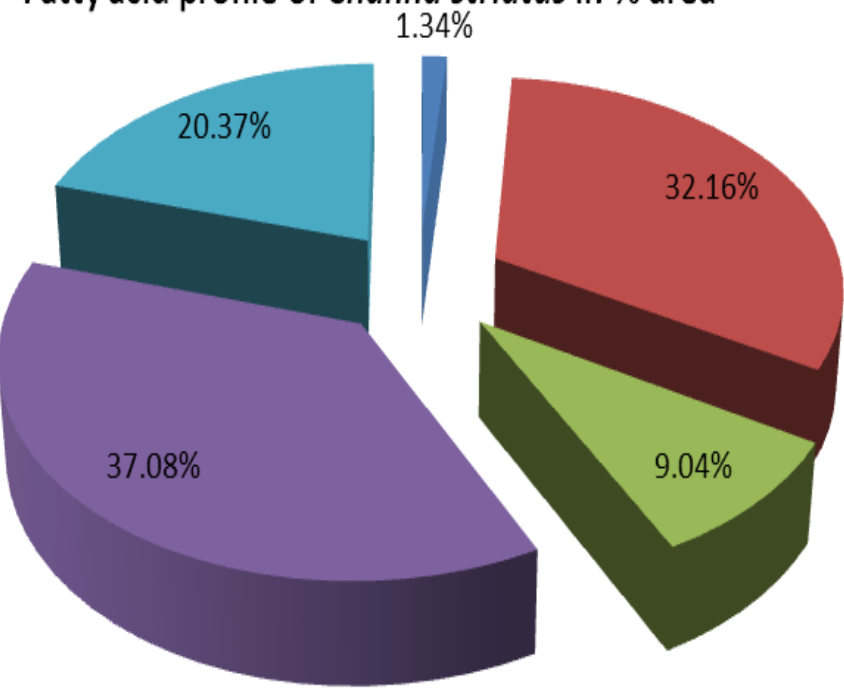

C14:0 Myristic acid

C16:0 Palmitic acid

C18:0 Stearic acid

C18:1(n-9) Oleic acid

C18:2(n-6) Linoleic acid

Figure 4. Fatty acid profile of Channa striatus fed with $\mathrm{F}_{4}(\mathrm{LINOL})$

Fatty acid profile of Channa striatus in \% area

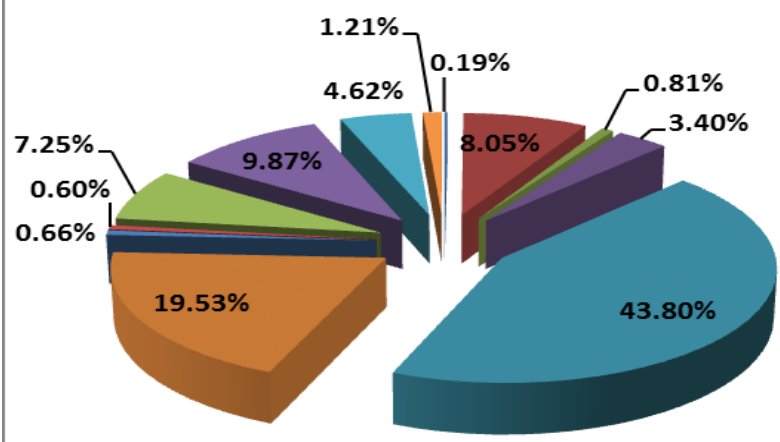

$$
\begin{aligned}
& \text { E13:0 Tridecyclic acid } \\
& \text { n C16:0 Palmitic acid } \\
& \text { n C16:1(n-9) Palmitoleate } \\
& \text { - C16:1(n-7) Palmitoleic acid } \\
& \text { n C18:1(n-9)+18:0 Oleic } \\
& \text { acid+Stearic acid } \\
& \text { C18:2(n-6) Linoleic acid } \\
& \text { - C18:3(n-3) Alpha-linolenic acid } \\
& \text { - C20:1(n-9) Eicosenoic acid } \\
& \text { - C20:3(n-7) Fatty acid } \\
& \text { - C20:4(n-6) Arachidonic acid } \\
& \text { - C20:5(n-3) Eicosapentaenoic } \\
& \text { acid } \\
& \text { C22:6(n-3) Docosahexaenoic } \\
& \text { acid }
\end{aligned}
$$

Figure 5. Fatty acid profile of Channa striatus fed with $\mathrm{F}_{5}$ (MIXOL) 


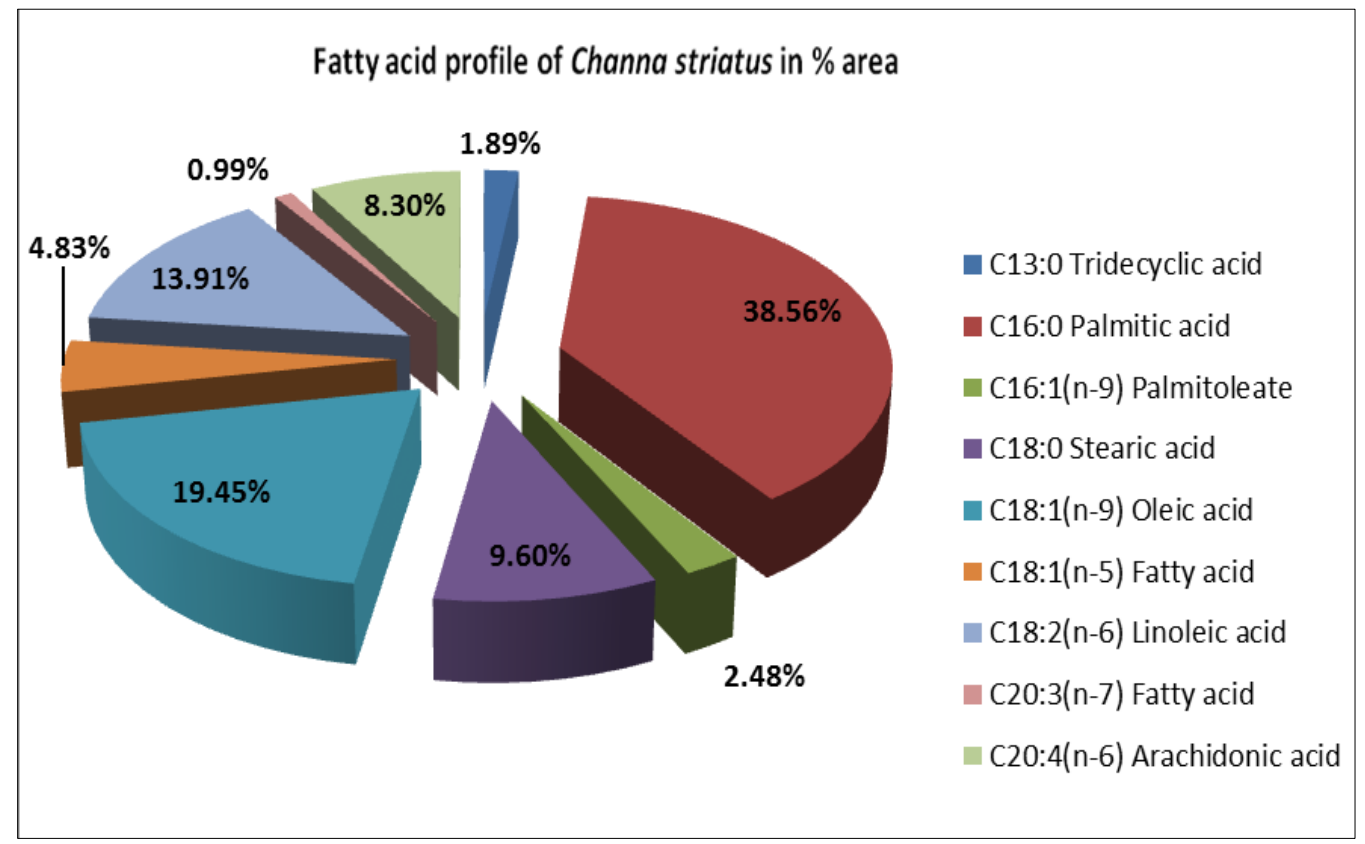

Figure 6. Fatty acid profile of Channa striatus fed with $\mathrm{F}_{6}(\mathrm{SATOL})$

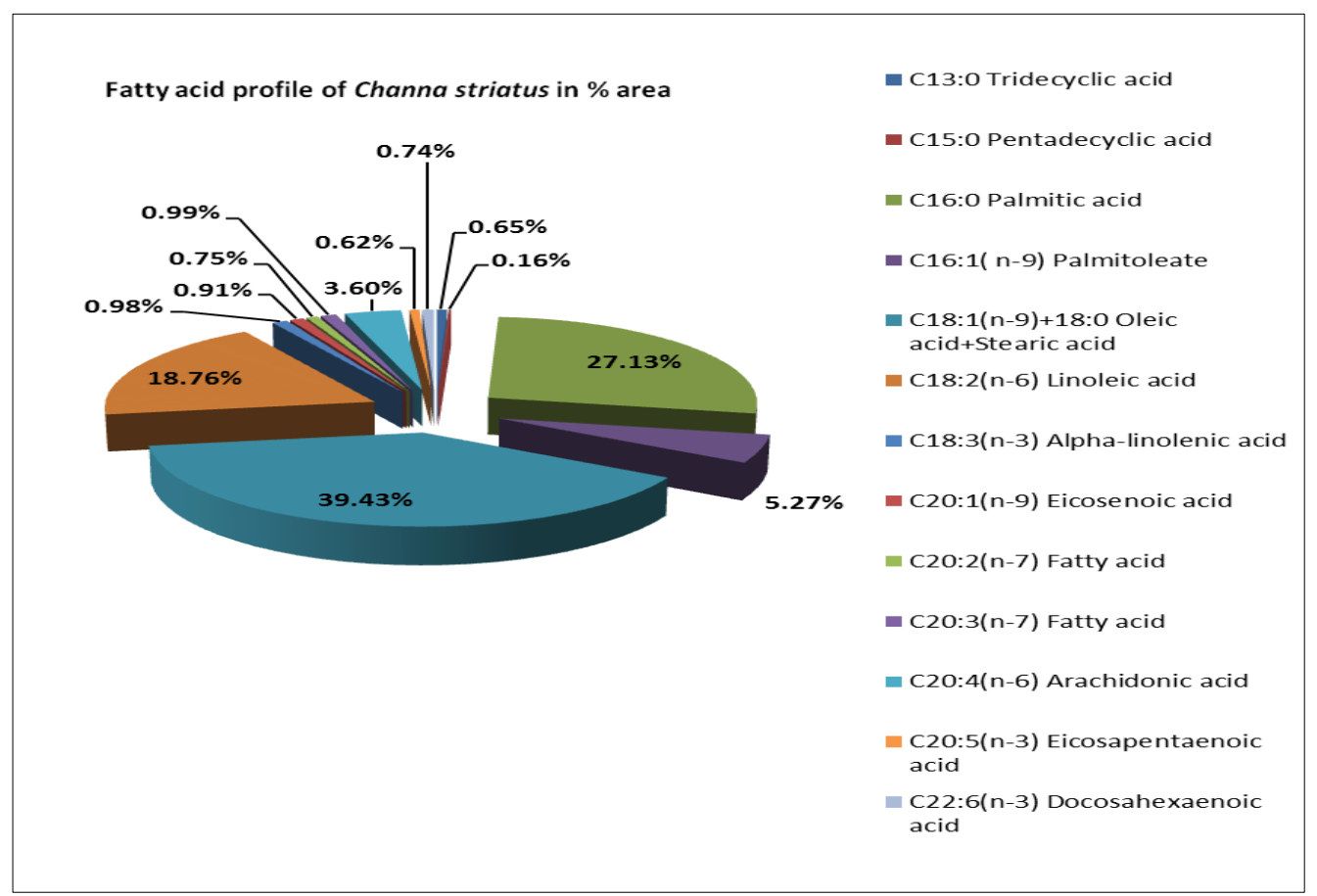

Figure 7. Fatty acid profile of Channa striatus fed with $\mathrm{F}_{7}$ (NATFO)

\subsection{Fatty Acid Composition}

A total fatty acids were identified in muscle tissue of Channa striatus fed with different diets are presented in Fig1-7 and results indicate that the carcass profile changes as per the dietary sources of the fats fed to the fishes.

In the earlier studies on fatty acids profiles of a marine fish, 15 fatty acids were identified by Gopakumar [19] and 19 were reported by Joydeep et al.[20]. In muscle tissue, the most important and common essential fatty acids like Arachidionic acid (AA, 20:4n-6) was the principal n-6 PUFA at a level of 3.6-9.87\% of total fatty acids. Eicosapentaenoic acid (EPA, 20:5n-3), and docosahexaenoic acid (DHA, 22:6n-3) were the major n-3 PUFA identified, accounting 0.82-4.62 and $0.74-1.21 \%$ respectively (Table 2). The detailed fatty acid composition of fish tissue are depicted in Table-3. 
Table 2. Important fatty acid profile of fish muscle

\begin{tabular}{|c|c|c|c|c|c|c|c|c|}
\hline Fatty Acid & $\begin{array}{c}\text { Emperical } \\
\text { formula }\end{array}$ & $\begin{array}{c}\text { F1 } \\
\text { (L3HUF) }\end{array}$ & $\begin{array}{c}\text { F2 } \\
\text { (H3HUF) }\end{array}$ & $\begin{array}{c}\text { F3 } \\
\text { (MUSOL) }\end{array}$ & $\begin{array}{c}\text { F4 } \\
\text { (LINOL) }\end{array}$ & $\begin{array}{c}\text { F5 } \\
\text { (MIXOL) }\end{array}$ & $\begin{array}{c}\text { F6 } \\
\text { (SATOL) }\end{array}$ & $\begin{array}{c}\text { F7 } \\
\text { (NATFO) }\end{array}$ \\
\hline Linoleic acid & C18:2(n-6) & 18.02 & 21.08 & 13.96 & 20.37 & 19.53 & 13.91 & 18.76 \\
\hline Alpha-linolenic acid & C18:3(n-3) & 0.62 & 0.95 & 0.44 & - & 0.66 & - & 0.98 \\
\hline Eicosenoic acid & C20:1(n-9) & 0.49 & 1.11 & 1.15 & - & 0.60 & - & 0.91 \\
\hline Arachidonic acid & C20:4(n-6) & 6.86 & 5.37 & 4.08 & - & 9.87 & 8.30 & 3.60 \\
\hline Eicosapentaenoic acid & C20:5(n-3) & - & 0.82 & - & - & 4.62 & - & 0.62 \\
\hline Docosahexaenoic acid & C22:6(n-3) & 0.76 & 1.16 & 0.41 & - & 1.21 & - & 0.74 \\
\hline
\end{tabular}

values are in $\%$

Table 3. Fatty Acid Composition of Channa striatus fish carcass

\begin{tabular}{|c|c|c|c|c|c|c|c|c|}
\hline Sr.NO. & Fatty Acid & $\begin{array}{c}\text { F1 } \\
\text { (L3HUF) }\end{array}$ & $\begin{array}{c}\text { F2 } \\
\text { (H3HUF) }\end{array}$ & $\begin{array}{c}\text { F3 } \\
\text { (MUSOL) }\end{array}$ & $\begin{array}{c}\text { F4 } \\
\text { (LINOL) } \\
\end{array}$ & $\begin{array}{c}\text { F5 } \\
\text { (MIXOL) }\end{array}$ & $\begin{array}{c}\text { F6 } \\
\text { (SATOL) }\end{array}$ & $\begin{array}{c}\text { F7 } \\
\text { (NATFO) } \\
\end{array}$ \\
\hline & & \multicolumn{7}{|c|}{ Percentage } \\
\hline 1 & $\begin{array}{c}\text { C13:0, Tridecyclic } \\
\text { acid }\end{array}$ & 0.59 & 0.58 & 0.64 & - & 0.19 & 1.89 & 0.65 \\
\hline 2 & C14:0, Myristic Acid & - & - & - & 1.34 & - & - & - \\
\hline 3 & $\begin{array}{c}\text { C15:0, Pentadecyclic } \\
\text { Acid }\end{array}$ & - & - & - & - & - & - & 0.16 \\
\hline 4 & C16:0, Palmitic Acid & 29.78 & 19.11 & 27.19 & 32.16 & 8.05 & 38.56 & 27.13 \\
\hline 5 & $\begin{array}{l}\text { C16:1 (n-9), } \\
\text { Palmitoleate }\end{array}$ & 0.41 & 3.70 & 2.68 & - & 0.81 & 2.48 & 5.27 \\
\hline 6 & $\begin{array}{c}\text { C16:1 (n-7), } \\
\text { Palmitoleic Acid }\end{array}$ & 3.17 & - & - & - & 3.40 & - & - \\
\hline 7 & C18:0, Stearic Acid & 7.35 & 9.29 & 11.79 & 9.04 & - & 9.60 & - \\
\hline 8 & $\begin{array}{c}\text { C18:1 (n-5), Fatty } \\
\text { Acid } \\
\end{array}$ & - & & - & - & - & 4.83 & - \\
\hline 9 & $\begin{array}{c}\text { C18:1 (n-9), Oleic } \\
\text { Acid }\end{array}$ & 30.76 & 34.55 & 36.06 & 37.08 & - & 19.45 & - \\
\hline 10 & $\begin{array}{c}\text { C18:1 (n-9), Oleic } \\
\text { Acid + C18:0, Stearic } \\
\text { Acid }\end{array}$ & - & - & - & - & 43.80 & - & 39.43 \\
\hline 11 & $\begin{array}{c}\text { C18:2 (n-6), Linoleic } \\
\text { Acid }\end{array}$ & 18.02 & 21.08 & 13.96 & 20.37 & 19.53 & 13.91 & 18.76 \\
\hline 12 & $\begin{array}{c}\text { C18:3 (n-3), } \\
\text { Alpha-linoleic Acid }\end{array}$ & 0.62 & 0.95 & 0.44 & - & 0.66 & - & 0.98 \\
\hline 13 & $\begin{array}{c}\text { C20:1 (n-9), } \\
\text { Eicosenoic Acid }\end{array}$ & 0.49 & 1.11 & 1.15 & - & 0.60 & - & 0.91 \\
\hline 14 & $\begin{array}{c}\text { C20:2 (n-7), Fatty } \\
\text { Acid } \\
\end{array}$ & - & 0.82 & 0.64 & - & - & - & 0.75 \\
\hline 15 & $\begin{array}{c}\text { C20:3 (n-7), Fatty } \\
\text { Acid } \\
\end{array}$ & 1.19 & 1.46 & 0.96 & - & 7.25 & 0.99 & 0.99 \\
\hline 16 & $\begin{array}{l}\text { C20:4 (n-6), } \\
\text { Arachidonic Acid }\end{array}$ & 6.86 & 5.37 & 4.08 & - & 9.87 & 8.30 & 3.60 \\
\hline 17 & $\begin{array}{c}\text { C20:5 }(\mathrm{n}-3), \\
\text { Eicosapentanoic Acid }\end{array}$ & - & 0.82 & - & - & 4.62 & - & 0.62 \\
\hline 18 & $\begin{array}{c}\text { C22:6 (n-3), } \\
\text { Docosahexaenoic } \\
\text { Acid } \\
\end{array}$ & 0.76 & 1.16 & 0.41 & - & 1.21 & - & 0.74 \\
\hline
\end{tabular}


The fatty acid composition of fish fillet in general is established and well known to be modified by diet [21], food efficiency [22] and non-food factors including climatic temperature[23].It has been documented that the PUFA content in fish and shellfish varies inversely with ambient temperature, while the SAFA content varies positively with ambient temperature[14]. Climatic temperature variations is known to affect the fatty acid profile of the fillet offish so that the unsaturation increases with lowering the temperature[24]. Though the total lipid content in the muscle tissue recorded was low, the concentration of EPA and DHA which are considered as human health beneficial fatty acids [20], observed towards high side. The fatty acid (FA) profile of C. striatus muscle was influenced by the FA composition of the feed, reported for many species [25-29]. The decline in PUFA in the muscle with different fats level at the FA levels are recorded in the present study. This observation concurs with what has been reported in the published materials, that dietary fat provide essential FA for the normal growth and development of body[30], and assure the established fact that the metabolic activities of carnivorous fish is set to a high level of intake protein[31]. It also indicates that $C$. striatus has the ability to differentiate between intake fatty acid, and using them for specific deposition and/or catabolize for energy release, similar to the results with other fish species reported by many researchers [27,28,32]. Bell et al.[33] had earlier reported that there is accumulation of MUFA and SFA being preferential substrates for beta-oxidation in salmonids. It is recorded that even overall, feed FA proximate commonly impact that of the carcass, alterations in the FA composition of carcass in this species followed alteration in the dietary FA composition and also changed among carcass lipid classes and between carcass, as similarly demonstrated by Trushenski et al.[34,35] for a lean fillet fish sp. This deduce that $C$. striatus conforms to the metabolic pattern in freshwater fish as ability of bioconversion of dietary fats to C20 and C22 HUFA as demonstrated by many researchers[36-38].

Evaluation of chicken fat and its mixture with cold-pressed linseed oil as supplemental dietary lipid for sablefish (Anoplopoma fimbria) assessed by Friesen et al.[40]. The linseed oil, has long been assessed as an alternative to fish oils in aquaculture feed. But only in the last decade it has been used for some marine species including: sablefish [39-41]; gilthead sea bream [6,42], European sea bass[6,43] and turbot $[7,44,45]$. Results from these studies indicate that dietary oil can be partially substituted with linseed oil, however, at higher substitution levels, reductions in growth may happen due to the deficiencies in n-3 HUFAs [6,42,43,45]. The same researcher group of present study, worked with same fish supplemented the MIXOL and it was recorded that the growth performance is improved in comparison to other groups [46]. The effects of different dietary fats on the fatty acid profile of $C$. striatus carcass of have been investigated in the present study. In all the treatments it is indicated that all types of oils tested in the study were impacting beneficial effects to striped murrel, Channa striatus, in terms of fatty acid profile, at their levels of maximum supplementation of $8 \%$. Hence they may be used in combinations which did create significant changes in carcass fatty acid profile in 12 week growth studies.

The sources of dietary fats positively affected the deposition of fatty acids (EPA and DHA) in this fish. This piece of research work may not be able to give an economical feed, as it is an indicative in the findings that various dietary fats alter the flesh composition, however, a cheaper natural lipid source may economize the cost of the brood-stock feed and for this more research is required in future.

\section{Acknowledgements}

Authors are very grateful to the Director, NBFGR, Lucknow for providing facilities to conduct this research work. Author (PPS) duly acknowledge the technical support for FA analysis by Ms. Madonna T. Thachil and Mr. Bhisham Dev Tyagi.

\section{REFERENCES}

[1] Riche, M. and Garling, D., 2003. North Central Regional Aquaculture Centre and United State Department of Agriculture USDA, pp 1-4.

[2] Sarowar, M.N., Jewel, M.Z.H., Sayeed, M.A. and Mollah, M.F.A., 2010.Impacts of different diets on growth and survival of Channa striatus grow-outs. Int. J. Bio. Res. 1(3):08-12.

[3] Aliyu-Paiko, M., Hashim, R., Alexandern, Shu Chien Chong., Yogarajah, L., Abdel Fattah, M. and Sayed, E.I., 2010. Influence of different sources and levels of dietary protein and lipid on the growth, feed efficiency, muscle composition and fatty acid profile of snakehead Channa striatus (Bloch, 1793) grow-out. Aquac. Res. 41(9):1365-1376.

[4] Caballero, M.J., Obach, A., Rosenlund, G., Montero, D., Gisvold, M. and Izquierdo, M.S., 2002.Impact of different dietary lipid sources on growth, lipid digestibility, tissue fatty acid composition and histology of rainbow trout Onchorhynchus mykiss Aquaculture, 214:253-271.

[5] Bell, J.G., McGhee, F., Campbell, P.J. and Sargent, J.R., 2003. Rapeseed oil as an alternative to marine fish oil in diet of post-smolt atlantic salmon (Salmo salar): changes in flesh fatty acid composition and effectiveness of subsequent fish oil wash out. Aquaculture, 218:515-528.

[6] Izquierdo, M.S., Obach, A., Arantzamendi, L., Montero, D., Robaina, L. and Rosenlund, G., 2003. Dietary lipid sources for seabream and seabass : growth performance, tissue composition and fish quality. Aqua.Nut., 9:397-407.

[7] Regost, C., Arzel, J., Robien, J., Rosenlund, G. and Kaushik, S.J., 2003. Total replacement of fish oil by soybean oil or linseed oil with a return to fish oil in turbot (Psetta maxima) I. 
Growth performances, flesh fatty acid profile and lipid metabolism. Aquaculture, 217:465-482.

[8] Erkkila, A.T., Lehto, S., Pyorala, K. and Uusitupa, M.I., 2003.N-3 Fatty acids and 5-y risks of death and cardiovascular disease events in patients with coronary artery disease. Amer. J. Clinical Nutr.,78:65-71.

[9] Dallongeville, J., Yarnell, J., Ducimetiere, P., Arveiler, D., Ferriers, J., Montaye, M., Luc, G., Evans, A., Bingham, A. and Hass, B., 2003. Fish consumption is associated with lower heart rates. Circulation, 108(7):820-825

[10] James, M.J., Gibson, R.A. and Cleland, L.G., 2000.Dietary polyunsaturated fatty acids and inflammatory media to reproduction. Amer. J. Clinical Nutr., 71:343S-348S

[11] Nichols, P.D., Mooney, B.D. and Elliott, N.G., 2002.Nutritional value of Australian seafood II. Factors affecting oil composition of edible species,

Report of the Fisheries Research and Development Corporation. CSIRO Marine Research, Hobart, Australia.199 $\mathrm{pp}$

[12] Exler, J., Kensella, J.E., Watt, B.K., 1975. Lipids and fatty acids of important finfish: new data for nutrient tables. J. Amer. Oil Chem. Soc., 52:154-159

[13] Bandara, N.M., Batista, I., Nunes, M.L., Empis, J.M., Christie, W, 1997. Seasonal changes in lipid composition of sardine (Sardina pilchardus). J. Food Sci., 62:40-42

[14] Dunstan, G.A., Olley, J. and Ratkowsky, D.A., 1999.Major environmental and biological factors influencing the fatty acid composition of seafood from Indo-Pacific to Antarctic waters. Rec. Res. Dev. Lipid Res.,3:63-86.

[15] Folch, J.L., Sloane, M. and Stanley, G.H.S., 1957.A simple method for the isolation and purification of total lipids from animal tissues. J. Biol. Chem.,226:497-509.

[16] A.O.A.C., 1995. Official methods of analysis of Association of Official Analytical Chemists, Volume I, 16th edn.AOAC International, Arlington, USA.

[17] Kleimenov, I.Y., 1971. Importance of fish as food. Moscow, Nauka.

[18] Tanaka, S.,1980. Biological research on salmon sharks (Lamna ditropis). Report on the research of new resources development on shark, Japan Marine Fishery Resources Research Center, pp. 59-84.

[19] Gopakumar, K.,1997.Indian food fishes: Biochemical composition. Central Institute of Fisheries Technology. Indian Council of Agricultural Research, Cochin, India, pp. 22- 28.

[20] Joydeep, D., Debasish, P., Bhattacharya, A., Chakraborty, J., Banerjee, D. and Ghosh, A.,1999. Comparative study on fatty acids and either lipids of fresh and sun-dried Bombay duck (Harpadon nehereus).J. Food Sci. Technol.,36 (6):506-510.

[21] Olsen,Y. and Skjervold, H.,1995. Variation in content of 3 fatty acids in farmed Atlantic salmon, with special emphasis one effects on non-dietary factors. Aquacult. Int.,3:22-35.

[22] De Silva, S.S., Gunasekera, R.M., Collins, R., Ingram, B.A., Austin and C.M.,1997. Changes in the fatty acid profile of the Australian short fin eel in relation to development J. Fish Biol., $50(5): 992-998$.
[23] Bell, M.V., Henderson, R.J. and Sargent, J.R., 1986. The role of polyunsaturated fatty acids in fish. Com. Biochem. Physiol.,83B:711-719.

[24] Morris, R J, Culkin, F (1989) Fish. In: Ackman R. G (Ed.), Marine biogenic lipids, fats and oils, CRC Press, Boca Raton, Florida, p. 145-178

[25] Watanabe, T.,1982. Lipid nutrition in fish. Comp. Biochem. Physiol.,73B:3-15.

[26] Morais, S., Bell, J.G., Robertson, D.A., Roy, W.J. and Morris, P.C., 2001. Protein/lipid ratios in extruded diets for Atlantic cod, Gadus morhua L. Effects on growth, feed utilization, muscle composition and liver histology. Aquaculture 203:101-119.

[27] Rosenlund, G., Obach, A., Sandberg, M.G., Standal, H. and Tveit, K., 2001. Effect of alternative lipid sources on long-term growth performance and quality of Atlantic salmon (Salmo salar L.). Aqua.Res.32(Suppl.1), 323-328.

[28] Bell, J.G., Henderson, R.J., Tocher, D.R., McGhee, F., Dick, J.R., Porter, A., Smullen, R.P. and Sargent, J.R., 2002. Substituting fish oil with crude palm oil in the diet of Atlantic salmon (Salmo salar) affects muscle fatty acid composition and hepatic fatty acid metabolism. J.of Nutr. 132, 222-230.

[29] Caballero, M.J., Obach, A., Rosenlund, G., Montero, D., Gisvold, M., Izquierdo, M.S., 2002. Impact of different dietary lipid sources on growth, lipid digestibility, tissue fatty acid composition and histology of rainbow trout, Oncorhynchus mykiss. Aquaculture, 214: 253-271.

[30] Sargent, J.R., Henderson, R.J. and Tocher, D.R., 1989.The lipids. In: Fish Nutrition (ed. by J.E. Halver), pp 154-218. Academic Press, New York, NY, USA.

[31] Bibiano Melo, J.F., Lundstedt, L.M., Meton,.I, Baanante, I.V. and Oraes, G., 2006. Effects of dietary levels of protein on nitrogenous metabolism of Rhamdia quelen (Teleostei: Pimelodidae). Comparative Biochemistry and physiology-Part A: Molecular \& Integrative Physiology,145:181-187.

[32] Torstensen, B.E., Fryland, L., Lie, O., 2004. Replacing dietary fish oil with increasing levels of rapeseed oil and olive oil effects on Atlantic salmon (Salmo salar) tissue and lipoprotein composition and lipogenic enzyme activities. Aqua. Nutr.,10 : 175-192.

[33] Bell, J.G., Henderson, R.J., Tocher, D.R., McGhee, F., Dick, J.R., Porter, A., Smullen, R.P., Sargent, J.R., 2001. Replacement of fish oil with rapeseed oil in diets of Atlantic salmon (Salmo salar) affects tissue lipid composition and hepatocyte fatty acid metabolism. Jour. of Nutr., 132: 222-230.

[34] Trushenski, J.T., Lewis, H.A., Kohler, C.C., 2008a. Fatty acid profile of sunshine bass: I. Profile change is affected by initial composition and differs among tissues. Lipids, 43:629-641.

[35] Trushenski, J.T., Lewis, H.A. and Kohler, C.C. 2008b. Fatty acid profile of sunshine bass: II. Profile change differs among fillet lipid classes. Lipids, 43: 643-653.

[36] Mourente, G. and Tocher, D.R., 1994. In vivo metabolism of [1-14C] linolenic acid (18:3(n-3) and [1-14C] eicosapentaenoic acid (20:5(n-3)) in a marine fish: time course of the desaturation /elongation pathway. Biochimica. Et Biophysica. Acta., 1212:109-118.

[37] Mourente, G. and Tocher, D.R., 1998. The in vivo incorporation and metabolism of [1-14C] linolenate (18: 
$3 n-3)$ in liver, brain and eyes of juveniles of rainbow trout Onchorhynchus mykiss L. and gilthead sea bream Sparus aurata L. Fish Physiol. and Biochem., 18:149-165.

[38] Tocher, D.R. and Ghioni, C., 1999. Fatty acid metabolism in marine fish: low activity of fatty acyl D5 desaturation in gilt head sea bream (Sparus aurata) cells. Lipids, 34:433-440.

[39] Friesen, E.N., Balfry, S.K., Skura, B.J., Ikonomou, M.G. and Higgs, D.A., 2011. Evaluation of cold-pressed flax seed oil as an alternative dietary lipid source for juveniles able fish (Anoplopoma fimbria). Aquaculture Research. doi: 10.1111/j.1365-2109.2011.03022.x.

[40] Friesen, Erin N,, Shannon, K., Balfry, Brent J.,Skura, Michael G., Ikonomou, Dave and A. Higgs., 2013a.Evaluation of cold-pressed flaxseed oil as an alternative dietary lipid source for juveniles able fish (Anoplopoma fimbria) Aqua. Res., 44:182-199.

[41] Friesen Erin N., Shannon, K. Balfry, Brent J, Skura, Michael, Ikonomou, Dave and A. Higgs, 2013b. Evaluation of poultry fat and blends of poultry fat with cold-pressed flaxseed oil as supplemental dietary lipid sources for juveniles able fish (Anoplopoma fimbria) Aqua. Res., 44:300-316.

[42] Izquierdo, M.S., Montero, D., Robaina, L., Caballero, M.J., Rosenlund, G. and Gine's, R., 2005. Alterations in fillet fatty acid profile and flesh quality in gilthead seabream (Sparus aurata) fed vegetable oils for a long period. Recovery of fatty acid profiles by fish oil feeding. Aquaculture, 250:431-444.

[43] Montero, D., Robaina, L., Caballero, M.J., Gines, R.,Izquierdo, M.S., 2005. Growth, feed utilization and flesh quality of European sea bass (Dicentrarchus labrax) fed diets containing vegetable oils: a time-course study on the effect of a re-feeding period with a $100 \%$ fish oil diet. Aquaculture, 248:121-134.

[44] Bell, J.G., Tocher, D.R., MacDonald, F.M. and Sargent, J.R., 1994. Effects of diets rich in linoleic (18:2n-6) and $\alpha$-linolenic $(18: 3 n-3)$ acids on the growth, lipid class and fatty acid compositions and eicosanoid production in juvenile turbot (Scophthalmus maximus L.). Fish Physiol. and Biochem., 13:105-118.

[45] Bell, J.G., Tocher, D.R., Farndale, B.M., McVicar, A.H., Sargent, J.R., 1999.Effects of essential fatty acid-deficient diets on growth, mortality, tissue histopathology and fatty acid compositions in juvenile turbot (Scophthalmus maximus). Fish Physiol. and Biochem., 20:263-277.

[46] Dayal, R., Srivastava, P.P., Bhatnagar, A., Chowdhary, S., Yadav, A.K., Jena, J.K., 2012. Influence of different sources of dietary lipid on the growth, feed efficiency and survival of snakehead Channa striatus (Bloch, 1793) grow-out. Natl. Acad. Sci. Letters, 35(6): 541-546. 